\title{
TAHAPAN PERKEMBANGAN DAN PEMBELAJARAN SEBAGAI LANDASAN KONSEP LIFE LONG EDUCATION: SEBUAH PEMIKIRAN ALI AHMAD MADKUR
}

\author{
Miftahul Huda \\ Universitas Muhammadiyah Bandung \\ hafidz.8770@gmail.com
}

\begin{abstract}
ABSTRAK
Penelitian ini menelaah pemikiran Ali Ahmad Madkur di dalam kitab Manhaj al-Tarbiyah fii al-Tashawwur al-Islami terkait dengan tahapan perkembangan dan pembelajaran. Penelitian ini menggunakan metode kualitatif dengan teknik library research. Hasil penelitian ini menyebutkan bahwa tahapan perkembangan manusia menurut Ali Ahmad Madkur terdiri dari 7 masa yaitu : 1) Masa Kehamilan (مرحلة الحمل), 2) Masa Penyusuan ( مرحلة (الرضاعة), 3) Masa Anak-Anak (مرحلة الطفولة), 4) Masa Peralihan dan Baligh ( مرحلة

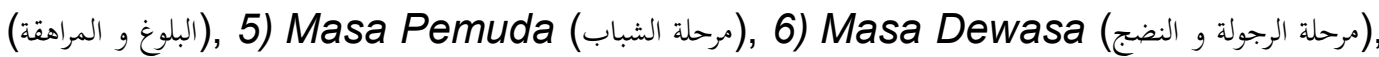
dan 7) Masa Tua (مرحلة الشيخوخة). Tahapan-tahapan perkembangan tersebut sebagai panduan dan landasan bagi seorang pendidik dalam memberikan pendidikan kepada anak didiknya. Berdasarkan pada tahapan-tahapan perkembangan tersebut maka pendidik diharapkan dapat menyesuaikan proses pelaksanaan pembelajaran menjadi lebih baik dan terukur, sehingga tujujuan pembelajaran yang telah dicanangkan dapat tercapai dengan baik. Dari tahapan-tahapan perkembangan ini pula, lahir konsep lifelong education yaitu konsep belajar sepanjang hayat. Oleh karena tahapan perkembangan manusia dimulai sejak lahir sampai dengan akhir hayatnya, maka proses belajaranya pun tidak boleh berhenti, untuk itulah kemudian di kenal pendidikan formal, informal dan non-formal. Sebagai salah satu wadah pendidikan sepanjang hayat.
\end{abstract}

Kata Kunci: Perkembangan, pembelajaran, lifelong education

\section{ABSTRACT}

This research examines the thoughts of Ali Ahmad Madkur in the Manhaj al-Tarbiyah fii al-Tashawwur al-Islami book regarding the stages of development and learning. This study uses qualitative methods with library research techniques. The results of this study indicate that the stages of human development according to Ali Ahmad Madkur consist of 7 periods, namely: 1) Pregnancy (مرحلة الرضاعة), 3 (مرحلة الحمل), Breastfeeding (مرحة)

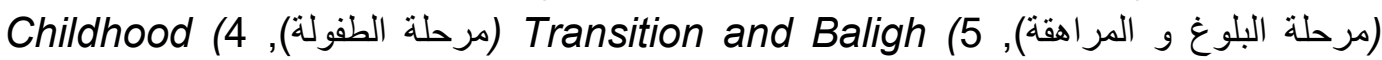

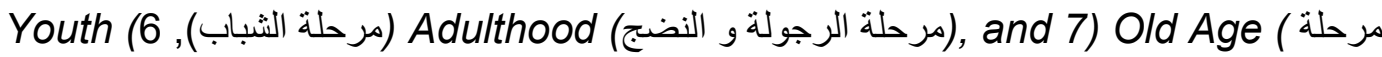


(الثيخوخة. These stages of development serve as a guide and foundation for an educator in providing education to their students. Based on these stages of development, educators are expected to be able to adjust the learning implementation process to be better and more measurable, so that the learning objectives that have been planned can be achieved properly. From these stages of development, the concept of lifelong education was born, namely the concept of lifelong learning. Because the stages of human development begin from birth to the end of life, the learning process must not stop, for this reason formal, informal, and non-formal education is known. As a place for lifelong education.

Keywords: development, learning, lifelong-education.

\section{PENDAHULUAN}

Pendidikan Islam adalah pendidikan yang fokus pada landasan al-Qur'an dan as-Sunnah. Sebab itu, tujuan pendidikan Islam tidak hanya berfokus kepada tujuan penguasaan keilmuan saja, namun juga bertujuan kepada penyiapan generasi di masa yang akan datang sebagai pemimpin di dunia sehingga dapat melaksanakan tugasnya dengan baik sesuai dengan panduan al-Qur'an dan as-Sunnah tadi.

Salah satu komponen yang tidak terlepas di dalam pendidikan Islam adalah peserta didik. Di dalam Undang-undang No. 20 Tahun 2003 tentang Sistem Pendidikan Nasional (Sisdiknas) disebutkan bahwa peserta didik adalah: anggota masyarakat yang berusaha mengembangkan potensi diri melalui proses pembelajaran yang tersedia pada jalur, jenjang, dan jenis pendidikan tertentu (Depdiknas, 2003). Dengan demikian, dari pengertian definisi tersebut di atas, penulis menyimpulkan ditinjau dari aspek pendidikan, peserta didik adalah sebagai objek dalam pendidikan diharapkan mampu mengembangkan potensi diri yang dimilikinya melalui proses pembelajaran.

Terkait dengan proses pembelajaran terhadap peserta didik, pendidik diharapkan mampu memahami tahapan dan tugas-tugas perkembangan peserta didik serta faktor-faktor yang dapat mendukung dan menghambat proses perkembangan sehingga dari pemahaman tersebut pendidik dapat mengikuti PBM dengan sebaikbaiknya sehingga tujuan pendidikan pun dapat terwujud.

Ali Ahmad Madkur di dalam kitab Manhaj al-Tarbiyah fi al-Tashawwur al-Islami menyatakan bahwa tahapan perkembangan manusia dipersiapkan oleh Allah untuk mendukung kurikulum pendidikan Islam. Setiap manusia memiliki potensi untuk mencapai derajat yang mulia apabila pelaksanaan pendidikan diupayakan 
bersesuaian dengan kondisi lingkungan pendidikan (diantaranya pada aspek tahapan perkembangan peserta didik) (Madkur, 2002).

Berdasarkan pemaparan tersebut, tulisan ini mencoba untuk mengulas kaitan tahapan perkembangan peserta didik dan proses pembelajaran sebagai landasan konsep life long education yang dianalisis menurut pemikiran Ali Ahmad Madkur di dalam kitab Manhaj al-Tarbiyah fi al-Tashawwur al-Islami.

\section{METODE PENELITIAN}

Penelitian ini menggunakan metode kualitatif. Sebagaimana yang diungkapkan Bogdan dalam Lexy J. Moleong adalah serangkaian tahapan penelitian yang menghasilkan data deskriptif berupa rangkaian kata baik lisan maupun tulisan dari orang-orang dan perilaku yang diamati. Pendekatan ini diarahkan kepada background maupun individu secara komprehensif. Jadi, dalam hal ini tidak boleh mengisolasikan individu atau organisasi ke dalam variabel atau hipotesis, tetapi perlu memandangnya sebagai bagian dari suatu keutuhan" (Moloeng, 1991).

Sedangkan teknik penelitian yang dipergunakan adalah teknik kepustakaan atau library research yaitu penelitian yang dilakukan dengan cara melakukan penelaahan dari hasil bacaan yang dilakukan oleh peneliti dari berbagai sumber literatur atau bahan bacaan yang sesuai dengan pokok bahasan, kemudian hasilnya direduksi dan dituangkan pembahasan penelitian ini (Kartono, 1998).

\section{PEMBAHASAN}

\section{Biografi Singkat Ali Ahmad Madkur}

Ali Ahmad Madkur merupakan salah satu ahli pendidikan Islam yang berasal dari Timur Tengah. Beliau di lahirkan di Kairo, Mesir. Gelar Sarjana pendidikan diraih di Al-Azhar University, Mesir. Pada tahun 2001 beliau dipercaya untuk menjabat sebagai Dekan pada Fakultas Tarbiyah di Universitas Sultan Qobus, Oman. Dan saat ini beliau menjadi Guru Besar (Profesor) di bidang pengembangan kurikulum. Sebagai guru besar yang ahli di bidang pengembangan kurikulum beliau aktif memberikan ceramah dan materi seminar di berbagai negara di Timur Tengah (Saqr, 2014).

\section{Tahapan dan Karakteristik Perkembangan Manusia}

Dalam beberapa kajian, para ahli lebih cenderung mengklasifikasikan tahapan perkembangan pada aspek post-natal saja, hal ini dapat dipahami dikarenakan

\footnotetext{
> Miftahul Huda | Tahapan Perkembangan dan Pembelajaran Sebagai Landasan Konsep Life Long Education: Sebuah
} Pemikiran Ali Ahmad Madkur 
4 | Tarbawi : Jurnal Pendidikan Islam Vol. 18. No. I. Januari - Juni 202l

tahapan pada aspek perkembangan ini terlihat jelas dan dapat diamati secara langsung. Meskipun, sebenarnya perkembangan manusia dimulai pada saat pembuahan di dalam rahim ibu.

Terkait dengan tahapan perkembangan manusia Ali Ahmad Madkur mengutip pendapat Ishaq Ahmad Farhan yang menyatakan bahwa tahapan-tahapan perkembangan yang dijelaskan oleh para ahli walaupun terkesan berbeda namun ternyata memiliki kemiripan. Hal itu tidaklah mengherankan, disebabkan karena pencipta manusia adalah Dzat yang Maha Esa yaitu Allah subhanahu wata'ala dan Bapak dari umat manusia berasal dari satu orang yaitu Adam 'alaihi salam. Adapun perbedaan tahapan-tahapan perkembangan tersebut, disebabkan karena faktor pemikiran, pengetahuan dan social-kemasyarakatan yang berbeda-beda (Madkur, 2002 : 166).

Selanjutnya Ali Ahmad Madkur memaparkan bahwa tugas-tugas perkembangan manusia dilalui secara berangsung-angsur dan terus menerus. Adapun pembagian tahapan perkembangan yang sesuai dengan landasan keislaman adalah:

1. Masa Kehamilan (مرحلة الحمل)

2. Masa Penyusuan (مرحلة الرضاعة) (ملةدة)

3. Masa Anak-Anak (مرحلة الطفولة) (ملة)

4. Masa Peralihan dan Baligh (مرحلة البلوغ و المر اهقة)

5. Masa Pemuda (مرحلة الثباب)

6. Masa Dewasa (مرحلة الرجولةو النضج)

7. Masa Tua (مرحلة الثيخوخة)

Tahapan perkembangan ini menurut Ali Ahmad Madkur sesuai dengan Firman Allah dalam surat Al-Hajj (22) ayat 5 sebagai berikut :

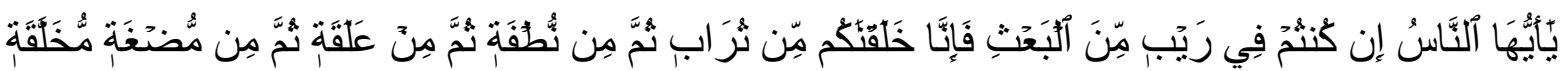

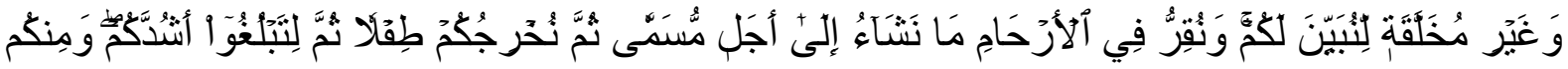

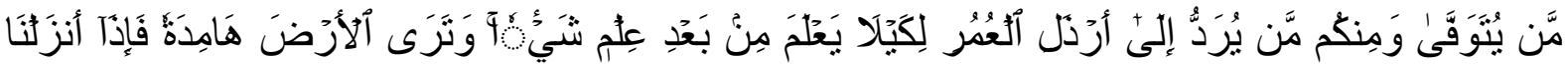

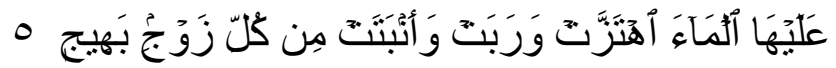
Wahai manusia, apabila kamu kamu meragukan (hari) kebangkitan, maka sesungguhnya Kami telah menjadikan kamu dari tanah, kemudian dari setetes mani, kemudian dari segumpal darah, kemudian dari segumpal daging yang sempurna kejadiannya dan yang tidak sempurna, agar Kami jelaskan kepada kamu dan Kami tetapkan dalam rahim, apa yang Kami kehendaki sampai waktu yang sudah ditentukan, kemudian Kami keluarkan kamu sebagai bayi, kemudian (dengan berangsur-angsur) kamu sampai pada usia dewasa, dan di 
antara kamu ada yang diwafatkan dan (adapula) di antara kamu yang dikembalikan sampai usia sangat tua (pikun), sehingga dia tidak mengetahui lagi sesuatu yang telah diketahuinya. Dan kamu lihat bumi ini kering, kemudian apabila telah Kami turunkan air (hujan) di atasnya, hiduplah bumi itu dan menjadi subur dan menumbuhkan berbagai pasangan tetumbuhan yang indah.

\section{a. Masa Kehamilan (مرحة الحمل)}

Dalam pandangan Islam, proses hidup manusia telah dimulai sebelum dia dilahirkan ke dunia. Manusia telah dianugrahkan ruh yang telah dihidupkan sebelum kelahirannya di dunia. Malaikat meniupkan ruh tersebut kepada manusia di dalam rahim ibunya sebelum dilahirkannya ke dunia.

Salah satu fase/tahapan perkembangan yang sangat penting dalam proses kehidupan manusia adalah ketika dia berada di dalam kandungan ibunya (prenatal). Pendidikan pre-natal merupakan proses pendidikan yang dilakukan oleh seorang ibu kepada janin yang dikandungnya sebelum melahirkan atau disebut juga dengan masa kehamilan. Secara umum masa ini berlangsung lebih kurang 9 bulan 10 hari. Masa pasca konsepsi mempunyai peranan yang sangat penting bagi proses pembentukan kepribadian manusia selanjutnya. Allah Swt menerangkan dalam firmannya :

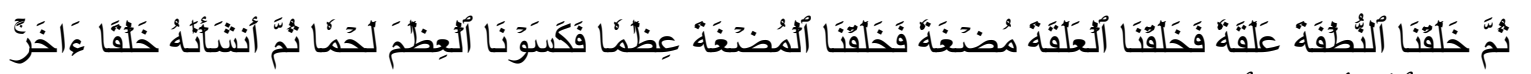

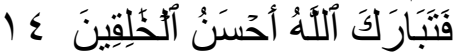

Kemudian air mani itu Kami jadikan sesuatu yang melekat, lalu sesuatu yang melekat itu Kami jadikan segumpal daging, dan segumpal daging itu Kami jadikan tulang belulang, lalu tulang belulang itu Kami bungkus dengan daging. Kemudian Kami jadikan dia makhluk yang (berbentuk) lain. Maka Maha sucilah Allah, Pencipta Yang Paling Baik (Q.S. Al-Mu'minun [23]: 14). Dari ayat tersebut, Allah memberikan informasi kepada kita mengenai masa kehamilan yang terbagi kepada 3 (tiga) tahap, yaitu: 1). Tahap "nuthfah", dalam bahasa biologi disebut dengan tahap germinal (pra-embrionik). 2). Tahap "alaqah" (segumpal darah), yang dikenal dengan tahap embrio. Tahap ini dilalui selama kurang lebih lima setengah minggu, dimulai ketika zigot sudah tertanam dengan baik pada dinding rahim. 3). Tahap "mudhghah", (segumpal daging), setelah kurang lebih 120 hari, 'alaqah akan menjadi segumpal daging. Kemudian dibentuk tulangbelulang sampai kepada penciptaan bayi dengan organ yang sempurna.

\section{b. Masa Penyusuan (مرحلة الرضاعة)}

> Miftahul Huda | Tahapan Perkembangan dan Pembelajaran Sebagai Landasan Konsep Life Long Education: Sebuah 
6 | Tarbawi : Jurnal Pendidikan Islam Vol. 18. No. I. Januari - Juni 202l

Masa penyusuan adalah masa yang sangat penting, dimana pada masa ini anak mendapatkan nutrisi yang sangat penting untuk perkembangannya lewat ASI yang diberikan oleh ibunya. Pemberian ASI oleh ibu menjadi suatu kewajiban yang harus dilakukan oleng sang ibu sebagai pemenuhan hak dari sang anak. Al-Qur'an menjelaskan terkait dengan urgensi dan pentingnya pemberian ASI kepada bayi sebagai berikut:

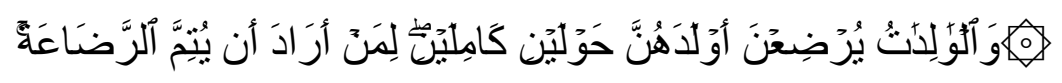

Dan para ibu-ibu hendaklah menyusia anak-anaknya selama dua tahun penuh, yaitu bagi yang ingin menyusui secara sempurna... (Q.S. Al-Baqarah [2]: 233)

Berdasarkan ayat tersebut dapat disimpulkan bahwa masa penyusuan berada pada periode usia 0-2 tahun (jika masa penyusuannya sempurna). Walaupun tidak dinyatakan bahwa pemberian ASI itu merupakan sebagai sebuah kewajiban melainkan berupa anjuran, namun ternyata antara bayi yang menerima ASI dari ibunya secara eksklusif dengan yang tidak menerima ASI secara eksklusif (dengan memberikan susu formula) memiliki perbedaan. Sebagaimana hasil penelitian Qurrota A'yun yang menyimpulkan bahwa terdapat perbedaan perilaku lekat bayi yang menerima ASI eksklusif dengan yang tidak menerima ASI eksklusif. Bayi yang menerima ASI eksklusif dari ibunya memiliki perilaku lekat bayi yang tinggi dibandingkan dengan yang non-eksklusif dari lbunya (A'yun, 2011).

Untuk itu dapat disimpulkan walaupun, pemberian ASI sebagaimana yang tercantum dalam surat Al-Baqarah ayat 233, bersifat anjuran. Namun maslahat yang didapatkan dengan memberikan ASI secara eksklusif lebih tinggi dibandingkan dengan tidak memberikan ASI secara eksklusif.

\section{c. Masa Anak-Anak (مرحلة الطقولة)}

Masa ini adalah masa lanjutan setelah masa penyusuan, menurut Faishal Khusni di dalam penelitiannya menyebutkan bahwa bahwa masa anak-anak (مرحلة (الطفولة ini berada pada rentang usia 2-14 tahun, yang secara garis besar tebagi kepada 2 fase, yaitu : 1) fase tufulah awal (2-7 tahun), dan 2) fase tufulah akhir (710 tahun). Selanjutnya, Faishal Khusni memaparkan terkait dengan 2 fase tersebut sebagai berikut (Khusni, 2018).

1) Fase Tufulah Awal (2-7 Tahun)

Tahapan Perkembangan dan Pembelajaran Sebagai Landasan Konsep Life Long Education: Sebuah Pemikiran Ali Ahmad Madkur | Miftahul Huda | < 
Fase ini merupakan fase dimana anak sudah mulai belajar dan paham bahasa ibunya dan pada fase ini pun anak dianjurkan untuk menekankan pendidikan dalam aspek pembentukan akhlak seperti anak diajarkan untuk melaksanakan kebiasaan yang baik dan menjauhi kebiasaan yang buruk.

\section{2) Fase Tufulah Akhir (7-10 Tahun)}

Pada fase ini anak sudah mulai memasuki masa perkembangan baru, yaitu perkembangan social. Anak sudah mulai mempelajari rasa simpati dan empati kepada sesama. Mereka pun sudah mulai nyaman bersama dengan teman sebayanya. Pada masa ini juga anak diajarkan tentang kedisiplinan dan tanggung jawab dalam melaksanakan sesuatu serta mulai mempelajari tentang komitmen dan konsekwensi dari norma-norma, nilai-nilai dan standar social yang ada di masyarakatnya.

\section{d. Masa Peralihan/ Pubertas dan Baligh (مرحلة البلوغ و المراهقة)}

Masa ini disebut juga dengan masa kritis, karena masa ini merupakan masa peralihan dari masa kanak-kanak menuju kedewasaan, masa ini berada pada rentang 10-14 tahun. Berbeda dengan masa sebelumnya, masa ini dititkberatkan pada pembentukan kedispilinan yang lebih tegas. Sebagai salah satu contohnya terkait dengan hadits Nabi yang memerintahkan untuk mengajarkan anak melaksanakan shalat pada usia 7 tahun dan "memukulnya" apabila pada usia 10 tahun masih tidak mau melaksanakan shalat. Pukulan yang diberikan oleh orang tua terhadap anak yang tidak mau melaksanakan shalat padahal usianya sudah 10 tahun merupakan bentuk konsekwensi sebagai seorang muslim.

Pada masa pubertas ini anak sedang pada tahap mencari jati dirinya sehingga terkesan menjadi pemberontak dan acuh terhadap sekelilingnya. Untuk itu orang tua maupun pendidik harus berhati-hati dan melakukan Tindakantindakan antispasi dalam menghadapi anak yang sedang dalam masa ini sehingga tidak salah mengarahkan untuk menghindari hal-hal yang tidak diinginkan.

Masa bermasalah dan kritis ini biasanya disebut sebagai "masa kejam" (biasanya berlangsung pada usia 10-11 tahun) meskipun berlangsung dalam masa yang singkat sekitar 1 tahun, namun sangat ditentukan oleh bimbingan orang tua dan pendidik karena akan menentukan perkembangananak pada fase selanjutnnya (Khusni, 2018).

\section{e. Masa Pemuda (مرحلة الثباب)}

$>$ | Miftahul Huda | Tahapan Perkembangan dan Pembelajaran Sebagai Landasan Konsep Life Long Education: Sebuah Pemikiran Ali Ahmad Madkur 
8 | Tarbawi : Jurnal Pendidikan Islam Vol. 18. No. I. Januari - Juni 202I

Masa ini adalah masa dengan rentang usia $\pm 14-40$ tahun, yang dalam istilah E. Hurlock merupakan masa dewasa awal (Jannah dkk., 2017). Adapun perbedaan antara teori tahapan perkembangan manusia E. Hurlock dengan tahapan perkembangan yang disampaikan oleh Ali Ahmad Madkur adalah tidak adanya fase atau masa remaja di dalam Islam. Kerena pada fase baligh seseorang sudah dianggap dewasa karena sudah terbebani hukum (taklifi), seperti terkena kewajiban sahalat, shaum, zakat dsb.

Adapun pada masa pemuda/dewasa awal ini terdapat perubahanperubahan yang dialami diantaranya adalah: perubahan fisik, penampilan, minat, sikap dan tingkah laku yang diakibatkan oleh penyesuaian diri disebabkan adanya tuntutan budaya dan harapan-harapan keluarga dan masyarakat terhadapnya (Jannah dkk., 2017).

Periode dewasa awal sering juga disebut sebagai early-adulthood. Adulthood yang berasal dari kata kerja "adultus" yang diartikan sebagai "tumbuh dan mencapai ukuran dan kekuatan yang penuh. Sehingga dapat diartikan bahwa masa ini adalah masa dimana seseorang telah menyelesaikan pertumbuhannya dan siap untuk berada dan berpartisipasi pada lingkungan social bersama dengan orang dewasa yang lainnya.

\section{f. Masa Dewasa (مرحلة الرجولة و النضج)}

Masa ini disebut juga sebagai masa dewasa madya (middle age), yang merupakan masa perubahan dari masa pemuda/dewasa awal yang diantara cirinya adalah: perubahan fisik disebabkan karena penuaan, kesepian disebabkan oleh ditinggalkan oleh pasangan hidup dan anak-anak yang sudah membangun keluarga sendiri. Selain itu juga pada masa ini sudah memasuki masa pensiun/ purna bakti sehingga dari faktor ekonomi/ pendapatan pun berbeda dengan ketika masih bekerja (Muzakkiyah \& Suharnan, 2016).

Dari ciri-ciri tersebut E. Hurlock menyebut masa ini sebagai masa sulit sepanjang rentang masa hidup manusia. Dari seberapa besar usaha seseorang untuk menjalani masa ini sangat ditentukan oleh dasar-dasar yang ditanamkan peda masa-masa perkembangan sebelumnya. Selanjutnya E. Hurlock menambahkan sebagaimana yang dikutip oleh Nurul Muzakiyah dan Suharnan, bahwa minat keberagamaan seseorang pada masa ini sangat berpengaruh kepada stabilitas psikologis seseorang dalam menghadapi kesulitan-kesulitan yang 
dihadapainya, peran minat keberagamaan ini pun berfungsi sebagai menurunkan stress dan rasa ketidakbahagiaan (Muzakkiyah \& Suharnan, 2016).

\section{g. Masa Tua (مرحلة الشيخوخة)}

Masa tua disebut juga sebagai periode dewasa akhir, Miftahul Jannah, dkk menyebutkan bahwa masa tua memiliki tugas-tugas perkembangan diantaranya adalah sebagai berikut: 1). Penyesuaian diri terhadap penurunan kesehatan dan kekuatan fisik, 2). Penyesuaian diri terhadap menghadapi masa pensiun dan penurunan penghasilan. 3). Penyesuaian diri terhadap kondisi ditinggalkan oleh pasangan hidup (Jannah dkk., 2017).

Dapat kita lihat dari tugas-tugas perkembangan di masa tua lebih didominasi kepada penyesuaian-penyesuaian terhadap kemunduran-kemunduran yang dialami, sehingga ada beberpa orang yang mampu melakukan penyesuaian, namun adapula yang terpuruk pada kondisinya sehingga menimbulkan sikap inferior disebabkan karena perubahan fisik serta mengasihani kondisinya saat ini.

\section{Tahapan Perkembangan dan Pembelajaran Ali Ahmad Madkur di dalam kitab Manhaj al-Tarbiyah fi al-Tashawwur al-Islami sebagai Landasan Konsep Lifelong Education}

Dari penjelasan terkait dengan tahapan-tahapan perkembangan khususnya yang disampaikan oleh Ali Ahmad Madkur nyatalah bahwa manusia sejak dalam kandungan sampai dengan akhir hayatnya memiliki tahapan-tahapan perkembangan yang memiliki ciri-ciri khas tersendiri. Maka dalam memberikan pendidikan pun harus disesuaikan dengan tahapan-tahapan perkembangan manusia itu. Maka dasar pemikirannya adalah karena penggolongan tahapan-tahapan perkembangan tersebut dari sejak dalam kandungan sampai dengan akhir hayat, maka pendidikan pun harus senantiasa diberikan dimulai dari dalam kandungan sampai dengan akhir hayat agar manusia tersebut dapat menyesuaikan dirinya di tengah lingkungan masyarakatnya sehingga bisa mendapatkan kebahagian dunia dan terlebih kebahagian di akhir, itulah yang menjadikan dasar pemikiran dari pendidikan sepanjang hayat dalam persepektif ilmu pendidikan Islam.

\section{a. Pendidikan Sepanjang Hayat/ Lifelong Education}

$>$ | Miftahul Huda | Tahapan Perkembangan dan Pembelajaran Sebagai Landasan Konsep Life Long Education: Sebuah Pemikiran Ali Ahmad Madkur 
IO | Tarbawi : Jurnal Pendidikan Islam Vol. 18. No. I. Januari - Juni 202I

Pendidikan sepanjang hayat dan belajar sepanjang hayat merupakan pengembangan potensi manusia melalui proses yang mendukung secara terus menerus yang menstimulasi dan memberdayakan individu-individu agar memperoleh semua pengetahuan, nilai-nilai, keterampilan-keterampilan dan pemahaman. Semua itu akan diperoleh dalam keseluruhan hidup individu dan kemudian menerapkannya dengan penuh percaya diri, penuh kreativitas dan menyenangkan dalam seluruh peran, iklim dan lingkungan (Longwort \& Davies, 1996).

Pengertian pendidikan sepanjang hayat dan belajar sepanjang hayat sering dipertukarkan dengan pemberian makna yang sama. Sesungguhnya kedua konsep tersebut saling mengisi dan tidak terpisahkan satu sama lain. Pendidikan sepanjang hayat (lifelong education) mengacu kepada serangkaian faktor-faktor ekstrinsik, berorientasi penyediaan (supply) dengan mengidentifikasi kebutuhan (the needs) dan penyediaan peralatan (the means).

Belajar sepanjang hayat (lifelong learning) ini berorientasi pada permintaan serta bergantung pada motivasi dan kemampuan dari peserta didik. Kedua hal ini harus memiliki keseimbangan agar dapat mencapai peningkatan kolaborasi dan outcome yang berorientasi pada produktifitas peserta didik. Secara komprehensif baik pendidikan sepanjang hayat maupun belajar sepanjang hayat dapat dipahami dengan gambaran skema "the whole DAMN cycle". DAMN cycle merupakan lingkaranlingkaran yang saling barkaitan antara Desire, Ability, Means dan Needs. Lingkaran DAMN di dalamnya terdapat pendidikan sepanjang hayat dan belajar sepanjang hayat. Lingkaran tersebut dapat digambarkan seperti di bawah ini.

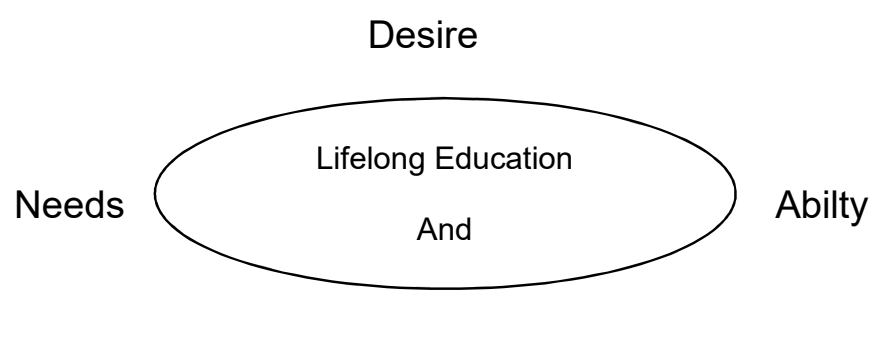

Means

Gambar 1 : The DAMN Cycle (Sumber: Huda, 2019)

\section{b. Hakikat Lifelong Education}

Sebagaimana yang telah dijelaskan sebelumnya bahwa pendidikan dan belajar sepanjang hayat diartikan sebagai usaha mengembangkan potensi manusia melalui

Tahapan Perkembangan dan Pembelajaran Sebagai Landasan Konsep Life Long Education: Sebuah Pemikiran Ali Ahmad Madkur | Miftahul Huda | $<$ 
proses yang saling mendukung secara terus menerus yang merangsang dan memberdayakan setiap individu agar mampu memperoleh semua pengetahuan, nilainilai, keterampilan-keterampilan dan pemahaman. Semua itu akan diraih dalam serangkaian tahapan-tahapan hidup individu dan kemudian hasilnya dapat diimplementasikan dengan penuh percaya diri, penuh kreativitas dan menyenangkan dalam seluruh perannya di masyarakat.

Pendidikan sepanjang hayat atai lifelong education, merupakan suatu inisiasi atau teori yang direkomendasikan sebagai suatu konsep besar dalam pengembangan inovasi di dunia pendidikan. Dengan kata lain konsep dari pendidikan sepanjang hayat tidaklah merupakan suatu jalur ataupun satuan dan atau program (sebagaimana ditegaskan dalam UU SISDIKNAS No. 20 Tahun 2003), melainkan suatu konsep sebagai pijakan dalam mengembangkan jalur ataupun satuan pendidikan. Hal ini perlu ditegaskan bahwa UUSPN No. 20 Tahun 2003 memberi landasan bahwa pendidikan nasional dilaksanakan melalui tiga jalur, yaitu pendidikan informal, formal dan nonformal (Yuhety dkk., 2008)

\section{c. Tahapan Perkembangan dan Pembelajaran sebagai Landasan Lifelong Education}

Dalam pandangan ilmu pendidikan Islam pada dasarnya manusia dilahirkan ke alam dunia ini dalam keadaan fitrah atau suci dengan Hadits Rasulullah SAW :

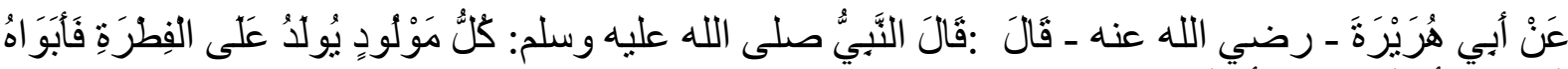

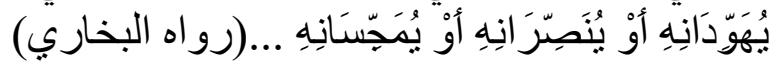

Dari Abu Hurairah r.a. ia berkata: telah bersabda Rasulullah SAW: Setiap manusia itu dilahirkan dalam keadaan suci (benar aqidahnya), maka kedua orang tuanyalah yang berperan dalam menjadikannya sebagai Yahudi, Nasrani atau Majusi...(H.R. Bukhari).

Islam memberi petunjik kepada umatnya untuk terus berusaha mancari ilmu pengetahuan tanpa memperhatikan usianya, selama masih dikaruniai hidup, selama mampu untuk menghirup udara, selama kmasih dapat bergerak, artinya kita wajib untuk mempelajari ilmu pengetahuan. Oleh karenanya ketika manusia dilahirkan ke alam dunia ini orang tua sudah mulai mengajarkan anaknya dengan berbagai hal yang

>| Miftahul Huda | Tahapan Perkembangan dan Pembelajaran Sebagai Landasan Konsep Life Long Education: Sebuah Pemikiran Ali Ahmad Madkur 
sudah barang tentu disesuaikan dengan usia dan tahapan perkembangan anak tersebut (Akyawi, 2009).

Pendidikan merupakan suatu proses usaha untuk dapat menghasilkan peserta didik yang memiliki ilmu pengetahuan, moral dan keterampilan. Pendidikan sebagai proses berarti pendidikan dimaksudkan sebagai penerapan berbagai usaha untuk mencapai tujuan-tujuan tertentu. Secara garis besar menurut pratiknya bahwa fungsi dari proses pendidikan itu meliputi tiga hal, yaitu (1) proses alih nilai (transfer of Value), (2) Proses alih pengetahuan (transfer of knowledge) dan (3) Proses alih metodologi (Transfer of Methodology) (Langeveld, t.t.).

Hasil pendidikan mencakup capaian dari perubahan yang telah diraih atau berlangsung sebagai hasil partisipasi peserta didik dalam proses belajar. Perubahan yang diraih sebagai hasil belajar hakekatnya merupakan petunjuk dalam mencapai tujuan pendidikan. Disisi lain tuntutan tujuan pendidikan akan berbeda-beda disebabkan faktor kultural dan kemampuan serta harapan pada tiap-tiap individu. Karenanya hasil pendidikan sebagai cerminan dari keseluruhan proses pembelajaran akan berbeda antara satu kelompok-kelompok kultural dan antar anggota kelompok yang sama. Berdasarkan hal tersebut hasil pendidikan dapat dijadikan sebagai gambaran tingkat pendidikan yang dimiliki oleh seseorang sebagai hasil pengalaman belajar yang dilakukannya. Namun sebagaimana yang diungkaplan oleh Plato bahwa sebenarnya hakikat pendidikan itu bukan hanya sekedar menerima pengetahuan saja, tetapi harus mengembangkan karakter sehingga dia dapat memahami hakikat diri yang merupakan hasil dari proses pembelajaran yang diterimanya. (Ebenstein, 1960).

Pendidikan sepanjang hayat merupakan satu konsep yang diantaranya mengembangkan pandangan berkaitan dengan belajar secara berkesinambungan dan terus (continuing-learning) dari sejak lahir sampai dengan akhir hayatnya, sejalan dengan tahapan-tahapan perkembangan pada manusia. Oleh karena setiap tahapantahapan perkembangan pada setiap manusia harus dilalui dengan proses belajar agar mampu melaksanakan tugas-tugas perkembangannya, maka belajar itu dimulai pada masa kanak-kanak sampai dewasa dan bahkan di masa tuanya, bertitik tolak pada tahapan-tahapan perkembangan pada manusia tersebut, berpengaruh kepada keharusan untuk belajar secara berkesniambungan dan terus menerus.

Ki Hadjar Dewantara megembangkan satu konsep pendidikan yang disebut dengan tripusat pendidikan yang menyatakan bahwa pendidikan dimulai ketika 
manusia tersebut dilahirkan atau dalam konsep pendidikan Islam disebut sebagai Tarbiyah Ba'da al-Wilâdah.

Konsep pendidikan sepanjang hayat atau yang dikenal dengan life long education atau biasa juga disebut long life education pada hakekatnya dapat dilakukan dimana saja, mulai dari lingkungan keluarga yang biasa disebut pendidikan informal yaitu dimulai dari masa kanak-kanak, remaja dan dewasa, bahkan sampai dengan usia tua. Belajar sepanjang hayat pun bisa dilakukan dalam pendidikan formal, dari mulai Play Group (PG) Taman Kanak-kanak (TK), Sekolah Dasar (SD), Sekolah Menengah Pertama (SMP), Sekolah Menengah Atas atau Kejuruan (SMA/SMK), Perguruan Tinggi (PT). Selain pendidikan informal dan formal ada juga pendidikan non-formal berupa pendidikan diluar pendidikan formal namun diseterakan dengan pendidikan formal karena memiliki kurikulum yang terstruktur dan berjenjang.

Lahirnya konsep pendidikan sepanjang hayat ini merupakan bagian dari keprihatinan terhadap dunia pendidikan yang ada saat ini, karena realitanya masih terdapat masyarakat yang tidak dapat menikmati pendidikan di dunia formal. Oleh karenanya proses belajar bisa dilakukan pada kegiatan non-formal, misalnya kegiatan pelatihan, kelompok belajar dan lain sebagainya.

Pendidikan sepanjang hayat merupakan tuntutan bagi kehidupan bagi manusia yang berakal, ini karena pendidikan adalah alat atau instrumen untuk menuju kesempurnaan hidup dan derajat sebagai manusia. Manusia dinyatakan sebagai manusia apabila mampu mengeksistensikan diri dalam kehidupannya melalui aktivitas berpikir, bersikap, dan bekerja, dimana aktivitas tersebut merupakan perangkat pendidikan.

Di dalam ajaran Islam, pendidikan merupakan salah satu kebutuhan yang harus diutamakan sebagai bentuk dari proses pemeliharaan diri, keluarga, dan masyarakat yang kemudian wujudnya direalisasikan dalam institusi pendidikan informal, formal dan non formal sebagai sarananya.

Berdasarkan pembahasan tersebut di atas, dapat dinyatakan bahwa pendidikan merupakan tuntutan bagi bagi manusia yang dianugrahi akal. Hal ini bersesuaian dengan petunjuk agama yang mewajibkan untuk menuntut ilmu diseoanjang hayatnya, hal ini agar manusia dapat merealisasikan eksistensi dirinya dalam kehidupannya dengan bentuk tindakan yang memiliki manfaat bagi dirinya maupun lingkungannya baik pada masa sekarang dan yang akan datang.

> Miftahul Huda | Tahapan Perkembangan dan Pembelajaran Sebagai Landasan Konsep Life Long Education: Sebuah Pemikiran Ali Ahmad Madkur 
14 | Tarbawi : Jurnal Pendidikan Islam Vol. 18. No. I. Januari - Juni 202l

Tujuan merupakan sesuatu yang dimaksudkan tercapai setelah proses usaha atau kegiatan selesai dilaksanakan. Artinya tujuan merupakan kehendak dari seseorang untuk meraih dan memiliki bahkan memanfaatkannya untuk kebutuhan dirinya sendiri atau orang lain (Budiman, 2001).Terdapat bermacam-macam pendapat yang disampaikan oleh para ahli pendidikan tentang tujuan dari pendidikan Islam. Diantaranya yang pernah dikemukakan oleh al-Nahlawi yang menyatakan bahwa tujuan pendidikan Islam adalah merealisasikan penghambaan kepada Allah dalam kehidupan manusia baik secara individual maupun secara sosial (Al-Nahlawi, 2001).

\section{SIMPULAN}

Perkembangan dan pembelajaran dalam prespektif Ali Ahmad Madkur di dalam kitab Manhaj al-Tarbiyah fi al-Tashawwur al-Islami adalah sebagai panduan dan landasan bagi seorang pendidik dalam memberikan pendidikan kepada anak didiknya. Berdasarkan pada tahapan-tahapan perkembangan tersebut maka pendidik diharapkan dapat menyesuaikan proses pelaksanaan pembelajaran menjadi lebih baik dan terukur, sehingga tujujuan pembelajaran yang telah dicanangkan dapat tercapai dengan baik.

Dari tahapan-tahapan perkembangan ini pula, lahir konsep lifelong education yaitu konsep belajar sepanjang hayat. Oleha karena tahapan perkembangan manusia dimulai sejak lahir sampai dengan akhir hayatnya, maka proses belajaranya pun tidak boleh berhenti, untuk itulah kemudian di kenal pendidikan formal, informal dan nonformal. Sebagai salah satu wadah pendidikan sepanjang hayat.

\section{DAFTAR PUSTAKA}

Akyawi, A. K. (2009). Al-Tarbiyah wa al-Ta'lim fi Madrasah al-Muhammadiyah (M. M. Ridha, Penerj.). Pusta Al-Kautsar.

Al-Nahlawi, A. R. (2001). Pendidikan Islam di Rumah, Sekolah dan Masyarakat. Gema Insani Press.

A'yun, Q. (2011). Perbedaan Perilaku Lekat Bayi Pada Orangtua Antara Yang Diberi Asi Eksklusif Dengan Yang Tidak Diberi Asi Eksklusif (Studi Pada Bayi Umur 6 Bulan - 3 Tahun Di Kecamatan Candi Kabupaten Sidoarjo). Psikologia : Jurnal Psikologi, 1(1), 53-67. https://doi.org/10.21070/psikologia.v1i1.739

Budiman, N. (2001). Pendidikan dalam Perspektif al-Qur'an. Madani Press.

Tahapan Perkembangan dan Pembelajaran Sebagai Landasan Konsep Life Long Education: Sebuah Pemikiran Ali Ahmad Madkur | Miftahul Huda | < 
Depdiknas. (2003). Undang-Undang Nomor 20 Tahun 2003 Tentang Sistem Pendidikan Nasional. Depdiknas RI.

Ebenstein, W. (1960). The Great Political Thinkers: Plato to Pressent. Holt Remhart and Wusroh.

Huda, M. (2019). Life Long Education in Islamic Perspective. International Journal of Nusantara Islam, 7(1), 40-48. https://doi.org/10.15575/ijni.v7i1.4006

Jannah, M., Yacob, F., \& Julianto, J. (2017). RENTANG KEHIDUPAN MANUSIA (LIFE SPAN DEVELOPMENT) DALAM ISLAM. Gender Equality: International Journal of Child and Gender Studies, 3(1), 97-114. https://doi.org/10.22373/equality.v3i1.1952

Kartono, K. (1998). Pengantar Metodologi Research. ALUMNI.

Khusni, Moh. F. (2018). Fase Perkembangan Anak Dan Pola Pembinaannya Dalam Perspektif Islam. Martabat: Jurnal Perempuan dan Anak - Pusat Studi Gender dan Anak (PSGA) IAIN Tulungagung, 2(2), 361-382. https://doi.org/10.21274/martabat.2018.2.2.361-382

Langeveld, M. J. (t.t.). Diklat Pedagogik. Gama.

Longwort, N., \& Davies, W. K. (1996). Lifelong Learning. Kogan Page Limited.

Madkur, A. A. (2002). Manhaj al-Tarbiyah fi al-Tashawwur al-Islami. Dar al-Fikr Araby. Moloeng, L. J. (1991). Metodologi Penelitian Kualitatif. PT Remaja Rosdakarya.

Muzakkiyah, N., \& Suharnan. (2016). Religiusitas, Penyesuaian Diri dan Subjektive Well Being. Persona:Jurnal Psikologi Indonesia, 5(01), Article 01. https://doi.org/10.30996/persona.v5i01.739

Saqr, M. J. (2014, Mei 24). Muhammad Ali Madkur. موقع الدكتور محمد جمال صقر. http://mogasaqr.com/2014/05/24/علي-مدكور/

Yuhety, H., Miarso, Y., \& Baslemah, A. (2008). INDIKATOR MUTU PROGRAM PENDIDIKAN SEPANJANG HAYAT. Jurnal Ilmiah Visi, 3(2), 150-170. https://doi.org/10.21009/JIV.0302.6

\footnotetext{
>| Miftahul Huda | Tahapan Perkembangan dan Pembelajaran Sebagai Landasan Konsep Life Long Education: Sebuah
} Pemikiran Ali Ahmad Madkur 